\title{
Környezettechnológiai kutatások a BME Alkalmazott Biotechnológia és Élelmiszertudományi Tanszéken
}

\author{
NÉMETH Áron*, FEHÉR Csaba, JOBBÁGY Andrea, MOLNÁR Mónika \\ BME Vegyészmérnöki és Biomérnöki Kar, Alkalmazott Biotechnológia és Élelmiszertudományi Tanszék, \\ Szent Gellért tér 4., H-1111 Budapest, Magyarország
}

\section{Bevezetés}

A BME-n kialakított biomérnök képzésnek egyik oszlopa a környezetvédelmi szemlélet. Az itt tanuló hallgatók valódi problémák megoldásának kutatásába is bekapcsolódhatnak BSc-től MSc-n át PhD-ig minden szinten.

Az Alkalmazott Biotechnológia és Élelmiszertudományi Tanszék (ABÉT) 2007. január 1-én jött létre a Biokémiai és Élelmiszertechnológiai Tanszék (BÉT) és a Mezőgazdasági Kémiai Technológia Tanszék (MGKT) egyesítésével. A megalakult új tanszék tudatosan törekszik alaptevékenységeinek - az oktatás, a kutatás-fejlesztésinnováció, valamint a szolgáltatások - korszerü, szakmailag hiteles, összehangolt és egymást erősítő müvelésére. Szakmai tevékenységük meghatározó területei a biokémia, molekuláris biológia, az élelmiszertudomány, az ipari, mezőgazdasági és környezetvédelmi biotechnológia valamint a kapcsolódó határterületek. A tanszék 4 kutatócsoportja mutatkozik be ebben a közleményben, amelyek közös vonása az alkalmazott kutatás végzése, és azon belül is a környezetvédelem számára különböző eljárások és technológiák kifejlesztése.

\section{A Fermentációs Félüzemben (F-Labor) zajló kutatások}

A biotechnológia és azon belül az alkalmazott mikrobiológia szinte minden fontosabb kurrens területén végzünk kutatásokat, most a környezetvédelmi vonatkozású témákat a Zöld Kémia 12 pontja ${ }^{1}$ mentén próbáljuk meg bemutatni.

\subsection{Megelőzés}

technológiák olyan kialakítása a legkiemeltebb cél, ahol nem keletkezik hulladék, mivel a hulladékok utólagos kezelése komoly erőfeszítéseket igényel a társadalom valamennyi résztvevőjétől, és a hatékonyság még így is viszonylag alacsony. Ilyen zéró landfill technológia kialakításáról már részben beszámoltunk a tejsav biofinomító kutatása során is ${ }^{\mathbf{2}, 3}$, ezért most egy másik egyszerü szerves sav a propionsav előállítással kapcsolatos eredményeinket mutatjuk be röviden a hulladék megelőzést szem előtt tartva.

A propionsavas kutatás motivációja az volt, hogy magyar tejgyárakkal együttmüködésekről egyeztetve kiderült, hogy bár évtizedek óta több 100.000 cikk jelent meg a tejsavó hasznosításáról, a magyar termelés fele még mindig hasznosítás nélküli. A tejsavó a tejipari termékek előállítása után visszamaradó híg vizes oldat, melyben max 5\% tejcukor, és 1-2\% tejsav található egy kevés maradék kazein mellett. Ezen értékek ahhoz magasak, hogy szennyvízkezelésre bocsássák, ahhoz pedig elég alacsonyak, hogy költséghatékonyan ki lehessen nyerni. Az első elgondolásunk olyan komplex tejsavó hasznosítást képzelt $\mathrm{el}^{4}$, amelyben a tejcukorból élesztő segítségével nagy hozzáadott értékü ergosterolt állítunk elő, a visszamaradt tejsavból pedig propionsavat. Az idézett publikációnkban ezen út folyamat-szimulációja azzal zárult, hogy a propionsavas út voltaképpen ráfizetéses, és csak annyit tesz hozzá a folyamathoz, hogy tovább csökkenti a KOI értéket. Ezért a legújabb tanulmányunk ${ }^{\mathbf{5}}$ során már mind a laktóz, mind a tejsav tartalmat propionsavvá alakítottuk úgy, hogy a laktózt 95-98\%-os hozammal tejsavvá fermentáltuk Lactobacillus casei segítségével, majd a teljes (induló + előállított) tejsav tartalmat propionsavvá fermentáltuk. Bár a Propionibacterium fajok a tejsavat jobban tudják hasznosítani a tejcukornál, a tejsavbaktériumok a tápközeg nitrogén tartalmát kissé kimerítették, ezért csak 32\%-os propionsav hozamot tudtunk elérni, amelynek fejlesztése jelenleg is folyik. Mivel azonban mind a LAB mind a PAB mikrobák a tejiparban használatosak, az eljárás várhatóan házon belül megoldja a hulladéktejsavó keletkezését.

\subsection{Atom hatékonyság}

Akár a korábbi publikációink, akár az előző bekezdés alapján jól látható, hogy a tejsav előállítás kimagasló hozammal rendelkezik, ami a bevitt szubsztrát közel teljes termékké alakítását teszi lehetővé azaz jó az atomhatékonysága. Korábban végeztünk már tejsav fermentációkat glükózból, cukorcirokléből,, jelenlegi kutatásaink pedig a glicerin és a melasz ${ }^{6}$ hasznosításra irányulnak, mivel ezek elérhető, megújuló és hozzáférhető ipari alapanyagok. A jelenleg vizsgált mikrobák estében a Bacillus coagulans képes a szacharózt hasznosítani és tejsavvá alakítani, azonban a Lactobacillus sp.-ek (pl. saját izolátumaink MKT878 és HMF) egy sterilezéssel kapcsolt invertálást követően magasabb hozamot és produktivitást értek el, mint spórás rokonaik. Szintén korábban sokat foglalkoztunk a költséges kiegészítő tápkomponensek (elsődlegesen élesztő kivonat) kiváltásával, illetve mennyiségének csökkentésével. Legújabb eredményeink szerint a kukorica csíra liszt is alkalmas nitrogénforrás, így 
az élesztőt csak nyomelem forrásként szükséges alkalmazni. Bár korábban is foglalkoztak már a melasz felhasználásával tejsav fermentációban, az előkezelések során keletkező melléktermékek (pl. HMF) akadályozták a fermentációt, mígnem hatékony enzimes illetve enyhe hőkezeléssel megtaláltuk a megfelelő melasz előkezelést. Így végül is kiterjesztettük az atomgazdaságosságot glükóz, cukorcirokszörpröl melaszra is.

\subsection{Kevésbé veszélyes szintézis}

A négy szénatomos cukoralkohol eritrit fermentációs előállítása ozmofil élesztőkkel lényegesen veszélytelenebb a drága eritróz alapanyag nagynyomású (tehát robbanásveszélyes) katalitikus hidrogénezésénél. Az eritrit fermentáció nehézsége a mikroba (esetünkben Moniliella pollinis) morfológiai viselkedésében rejlik. Dimorf gombáról lévén szó, hajlamos fonalas és élesztős morfológiában is növekedni, de az eritrit termelésnek az utóbbi kedvez. Megfelelő ozmolaritás és levegőztetés mellett sikerült 44\%-os hozammal $150 \mathrm{~g} / \mathrm{L}$ fölötti eritrit koncentrációt elérni $350 \mathrm{~g} / \mathrm{L}$ cukorból ${ }^{7}$.

\subsection{Biztonságosabb kemikáliák tervezése}

A kemikáliák használatának egyik legvitatottabb módja a peszticidek alkalmazása a mezőgazdaságban. Az F-laborban a biopeszticidek közül az entomopatogén Metarhizium anisopliae alapú kukoricabogár illetve kullancsölő szerek fejlesztése történik közel 6 éve $^{8}$. Jelen kutatás során számos nehézséggel kell megküzdeni: a) ez a fonalas gomba inkább szilárdfázisú fermentációkban tenyészthető szemben a hatékonyabb szubmerz eljárással; b) a gombán kívül a célrovarokat is fent kell tartani a laborban, c) célszerü vizsgálni a gomba specifitását, nehogy más fajokat (pl:háziméh) is megtámadjon, d) ez is polimorf gomba azaz számos megjelenési formája van. Kutató csoportunknak sikerült már kis léptékben élesztő morfológiát fenntartva koncentrált tenyészetet előállítani, amellyel (egyelőre csak elpusztult) kukorica bogarak sikeresen fertőzhetőek voltak.

\subsection{Biztonságosabb oldószerek és segédanyagok}

Bár oldószerek fermentációjára is van példa (aceton, butanol stb.) most egy olyan biztonságos segédanyagot mutatunk be, amelyet sikeresen alkalmaztunk bioszorbensként és több mint 3 éve vizsgáljuk a hatékony előállítását és használatát. Célunk, hogy a bányászati meddőkről elszivárgó csurgalékvíz molibdén tartalmát határérték alá csökkenthessük. Az általunk előállított bioszorbens használata kockázat nélküli, mivel a természetben is gyakori nitrogénfixáló mikoorganizmus az Azotobacter. vinelandii az alapja. A választást az indokolta, hogy a nitrogénkötés kulcsenzimének kofaktora éppen a molibdén, amelyből ezek a mikrobák a szükségesnél jóval többet tudnak raktározni egy speciális molibdén-kötő raktárfehérje segítségével, így elég szelektíven sok molibdént tudnak eltávolítani a tápanyagokkal kiegészített csurgalékvízből.

\subsection{Energia hatékonyság}

A cellulóz egy igen értékes anyag, amelyet jellemzően az olcsó mezőgazdasági hulladékokból állítanak elő. A növényekben azonban a cellulóz a ligninnel és ötszénatomos cukrokkal komplex rendszert alkot, amelynek megbontásához hőkezelésre és savas vagy lúgos hidrolízisre van szükség. Kutatásaink során Komagaeibacter xilynus baktériummal állítottunk elő mikrokristályos cellulózt, jelenleg az előállítás fejlesztése, optimálása zajlik. Mivel a termelés szobahőmérsékleten zajlik, és a kinyerés szüréssel vagy centrifugálással megvalósítható, jelentős energiamegtakarítás érhető el a növényi cellulóz kipreparálásához képest. A termék pedig vékonyabb szálú, de nagyobb szakítószilárdságú és nagyobb tisztaságú a bakteriális cellulóz esetében. A kutatás nehézségét itt is az analitikai problémák okozzák, mivel a terméket és a mikrobákat nehéz külön-külön meghatározni, valamint a terméket és a szubsztrátot is nehéz egymás mellett mérni, mivel a termék cellulózt is (kipreparálva tömeg alapon vagy elhidrolizálva) glükóz ekvivalensben szokás kifejezni. Ezen fermentáció reológiai nehézségeket is rejt (begélesedik a fermentlé), ami a keverést és a reprezentatív mintavételt nehezíti meg. Jelenleg folyó vizsgálataink során ezért forgókémcsöves tenyésztést alkalmazunk.

\subsection{Megújuló nyersanyagok használata}

Egy fiatal kutatás a csoportunk munkájában a légylárva alapú biofinomító, amely során elhullott állati tetemekből előbb légylárvák keletkeznek, majd abból lipideket és fehérjéket valamint kitint lehet extrahálni. A kutatás korai státusza és az ipari partner érdekeinek védelme okán egyelőre erről többet nem publikálhatunk.

\subsection{Származékképzés csökkentése}

Iparban is használatos eljárás a szteránvázas molekulák komplikált totál szintézise helyett a kész (pl. növényi) szteránvázak módosítása. Hasonlóképpen indítottuk 4 éve ergosterol (pre-D2 vitamin) fermentáció kutatásunkat, melyet tavaly kiegészítettünk 25-hidroxilezéssel az aktív D2 vitamin előállítása céljából. Így a P450 citokrómmal rendelkező mikrobák egylépésben védőcsoportok és származékok nélkül közvetlenül el tudják végezni a szintézist. A biokonverziós hatékonyságról még nem tudunk beszámolni, első lépésben a megfelelő citokróm hatékony előállítása a kitüzött cél.

\subsection{Katalítikus mennyiségü (és nagyon szelektív) reagensek}

Kutató csoportunk 16 éve foglalkozik az 1,3-propándiol koenzimregenerálásos enzimes biokonverzióján. A módszer lényegesen szelektívebb a fermentációs megoldásnál és a kémiai szintézisnél is, azonban számos kihívással jár, mivel a szükséges enzimek kereskedelmi forgalomban nem lévő, nehezen előállítható fehérjék. A legtisztább technológia az enzimes, mivel sem sejt, sem idegen metabolit nem 
keletkezik, tehát a kismennyiségű enzimek igen szelektívnek bizonyultak ebben az esetben. Az eljárást részletesen már e folyóiratban is bemutattuk, amelynek lényege, hogy glicerin diszproporciójával 3 kulcsenzim segítségével 1,3-propándiol és 1,3-dihidroxiaceton állítható elő a $\mathrm{NAD} / \mathrm{NADH}_{2}$ koenzimregenerálás közben. A fejlesztés legnagyobb problémája az első vízkilépési folyamat az 1,3-propándiol úton, amelyhez általában B12 vagy SAM koenzimet igénylö enzimet szokás használni. Sajnos ez öninaktiválódást szenved, ezért ennek megfelelő alternatíváját kerestük, lehetőleg fakultatív anaerob mikrobában. Egy újonnan leírt mikroba a Shimwellia blattae, amely az Escherichia. coli rokona, így nem zavarja a légköri oxigén, viszont szemben az $E$. coli-val képes de novo $\mathrm{B}_{12}$ szintézisre. Érdekes módon a $S$. blattae DSM4481 (=ATCC29907) nem termelte a kulcsenzimeket szinte semmilyen körülmény mellett sem (egyes irodalmak szerint egy vírus fertőzés következtében a kódoló génbe egy $M u$ fág génszakasz került), míg a S.blattae ATCC33430 jó propándiol és enzim termelő. Bár egy ilyen mikroba használata sokat lendít az enzimek előállításán, a $\mathrm{B}_{12}$ mediált inaktiválódást nem oldja meg, így az ideális enzimforrás megtalálása továbbra is egyik fő feladatunk.

\subsection{Lebomlásra tervezve}

Egy tipikus példa a biodegradálható müanyagokra a politejsav, amely müanyag alapanyag, monomerének fermentációs kutatásait már bemutattuk.

Hasonlóan nagy jelentőségü a szintén több mint 3 éve elkezdett biodetergensek fermentációs előállításának kutatása. Ezen molekulák fizikai-kémiai paraméterükben is versenyképesebbek a kémiai társaiknál, továbbá legfőbb előnyük a biodegradálhatóság. Mint már számos esetben, itt is a termék analitikája okozta az első kihívásokat, mivel a biodetergensek elég változatos szerkezetü molekulák (pl.: fehérje alapú vagy cukor alapú detergensek), így számunkra legcélszerübbnek a detergens hatás nyomonkövetése tünt. Erre kapilláris módszert adaptálva megvizsgáltuk a termékelőállítás hőmérséklet függését, amely alapján megállapítottuk, hogy a mikroba növekedés optimuma alacsonyabb $\left(30^{\circ} \mathrm{C}\right)$ mint a termékképzésé $\left(40^{\circ} \mathrm{C}\right)$, ezért a jövőben a kétszakaszú biodetergens fermentáció vizsgálata az egyik kitüzött célunk.

\subsection{Real-time analízis a szennyezés megelőzéséért}

Egyik legújabb kutatásunk az évek óta kis és nagy léptékben tenyésztett mikroalgák mellett a diatómák (=kovamoszatok) fermentációja. Mint ismeretes, a kovamoszatok egyes fajai igen érzékenyen reagálnak a környezeti paraméterek legenyhébb változásaira is, ezért környezeti monitoring során is használják őket. Amennyire előnyös az érzékenységük a környezeti monitoring szempontjából, annyira hátrányos az izolálásuk és tenyésztésük szempontjából. A legszelektívebb tápközegen is gyakorta előbb jelennek meg a zöldalgák, mint a diatómák, az amerikai törzsgyüjteményből Magyarországra utazást pedig 2 féle diatóma sem élte túl. Végül sikerült diatómában dús tenyészetet elöállítanunk, amely azonban még nem volt monokultúra, mert a leggyakoribb törzs (Naviculata) is csak $50 \%$ körül volt benne megtalálható izolálási helytől függetlenül. Ugyanakkor az izolátum preparálással párhuzamosan online mérörendszer fejlesztése is megkezdődött holografikus mikroszkópizálás segítségével. Ez az új technika egy kis cellatérfogatot fényképez le digitálisan egy fókuszponttal, így az ettől eltérő síkban lévő sejtek kissé életlenek lesznek, de szoftveresen kiélesíthetők. Ezt az eszközt bioreaktorokhoz kapcsolva folyamatosan és kontamináció nélkül lehet információt nyerni a tenyészetről, illetve a fejlesztett adatbázis segítségével a lefényképezett mikrobák automatikusan azonosíthatóak. E rendszer fejlesztéséhez egyelőre jelenleg még nagyobb méretü sejtek szükségesek, amely célnak a tenyésztett diatómák jól megfelelnek.

\subsection{Eredendően biztonságosabb anyagok tervezése a balesetek elkerülésére}

A legbiztonságosabb kémia a biokémia. Így tehát bármely bioszintézis alapú kutatásunk idesorolható, mint például: tejsav, propionsav, borostyánkősav fermentációs kutatása. A bio-biztonsághoz legszorosabban azonban az impedimetriás mikroba kimutatás és kvantifikálás területén végzett kutatásaink kapcsolódnak.

Számos biotechnológiailag előállított termék esetében szigorú mikrobiológiai tisztasági illetve stabilitási elöírásnak kell megfelelni. Például mind az élelmiszerekben mind a kozmetikumokban nem megengedett a Staphylococcus aureus és a Pseudomonas aeruginosa gennykeltö baktériumok jelenléte, de további mikrobákra is vizsgálni kell a termékeket (gomba szám, coliform mikrobák stb.). A tisztaság vizsgálatok esetében a mintákból higítási sort klszítenek, amelynek minden tagját min. 3 petricsészére kiszélesztik, így 1-1 mikroba jelenlétének és mennyiségének meghatározásához is $15-20$ petri csésze szükséges, mivel általában 5 mikrobára kell vizsgálódni ez a szám akár 100 tenyésztés is lehet, ami nagy manuális munkavégzést és jelentős anyagfelhasználást eredményez. Ezek kiváltására és csökkentésére a Sy-Lab (Ausztria) BacTrac készülékét adaptáljuk, amely 40 mérőcellát tud egyszerre kezelni, és ahol a tenyésztéseket impedimetriás módon lehet nyomon követni. Ezen módzser egyik előnye, hogy igen érzékeny, ezért nem kell 72h-n át várni a tenyésztési eredményre mint a klasszikus agarlemezeknél, mivel már $8-24 \mathrm{~h}$ alatt is általában jól elkülöníthető jelet ad a háttértől. Mivel a mért relatív impedancia változás kirajzolja a klasszikus sejtnövekedési görbét, egy elöre definiált impedancia küszöb eléréséhez tartozó idő a detektációs idő, ami a minta csíra számával fordítottan korrelál, ezért alkalmas a minták fertőzöttségének megállapítására. Ezt a készüléket a mikrobiológiai stabilitás vizsgálatra is adaptáltuk, ahol a vizsgálat kezdetén különböző mikrobák ismert mennyiségével kell a mintákat megfertőzni, majd hetente a készülék segítségével megmérni az egyes mikrobák csíraszámát detektációs idő vs telepszám (CFU) kalibráció alapján. Ideális esetben gyors csökkenés tapasztalható a mikrobaszámban, amelynek mértékből az eltarthatóság is jósolható. Ezen méréseket termékfejlesztéseinkhez is felhasználjuk, hogy biztonságos termékeket fejlesszünk és gyártsunk (pl . tartósítószerek vizsgálata). 


\section{A Környezeti Mikrobiológia és Biotechnológia Csoport kutatásai}

A BME ABÉT Környezeti Mikrobiológia és Biotechnológia Kutatócsoportja több mint 25 éve foglalkozik a környezeti kockázatmenedzsment két fő problémakörét - a környezeti kockázatfelmérést valamint a kockázatcsökkentést támogató eszköztár fejlesztésével, bővítésével, ezen módszerek és eljárások alkalmazásával környezetvédelmi technológiákban, valamint a kapcsolódó tudás és ismeretanyag elérhetővé tételével.

\subsection{Környezeti kockázatfelmérés}

Csoportunk tagjai sokrétű tapasztalattal rendelkeznek a vegyi anyagok és szennyezett területek kvantitatív környezeti kockázatfelmérése, valamint az ehhez kapcsolódó talaj és víz tesztelésére alkalmazható környezettoxikológiai tesztmódszerek fejlesztése terén. Partnereinkkel együttmüködve komplex környezeti kockázatfelmérést végeztünk szénhidrogénekkel szennyezett területeken, továbbá a gyöngyösoroszi ércbánya és az ajkai vörösiszap katasztrófa területén is. A környezeti kockázatfelméréshez integrált monitoring módszeregyütteseket dolgozunk ki; ezeknek részeként kiemelt hangsúlyt kapnak a talajmikrobiológiai és környezettoxikológiai módszerek, melyekkel a szennyezőanyagok valós kockázata jellemezhetö.

A kutatócsoport nevéhez füződik a szennyezett környezet monitorozásában szerepet játszó „direkt toxicitás mérés” kiterjedt alkalmazása ${ }^{9}$, több direkt kontakt talajteszt és szubletális végpontot alkalmazó víztoxikológiai teszt fejlesztése, egyrészt bakteriális (pl. Aliivibrio fischeri biolumineszcencia gátlási teszt, Salmonella typhimurium mutagenitási teszt), valamint növényi (pl. Lemna minor, Sinapis alba, Triticum aestivum), továbbá egysejtü (pl. Tetrahymena pyriformis) és többsejtü (pl. Daphnia magna, Heterocypris incongruens, Folsomia candia) állati tesztorganizmusokkal.

Vízkészleteink világszerte növekvő szennyeződése vegyi anyagokkal, köztük számos újonnan felismert káros hatású mikro-szennyezőanyaggal, napjaink környezetvédelmének egyik legégetőbb problémája. Így az utóbbi években a csoport kutatásaiban is fontos szerepet kap a környezettoxikológiai módszerek alkalmazhatóságának tesztelése és problémaspecifikus továbbfejlesztése ezen kis koncentrációban jelenlévő, biológiailag aktív mikro-szennyezőanyagok, köztük nanoanyagok, mint környezeti stressztényezők hatásának vizsgálatára, illetve korai jelzésére ${ }^{10}$. A csoport kiemelt hangsúlyt fektet a mérési eredmények értékelésére és a környezetirányítási döntések meghozatalában való hasznosítására is.

\subsection{Környezeti kockázatcsökkentés \\ 3.2.1. Talaj-és talajvíz remediáció}

A szennyezett területek kockázatcsökkentéséhez kapcsolódva innovatív környezetbarát remediációs technológiák fejlesztése áll kutatás-fejlesztési tevékenységünk középpontjában. Munkáinkban kiemelt szerepet kapnak egyrészt a természetes folyamatok intenzifikálását célzó mérnöki megoldások a szerves szennyezőanyagokkal szennyezett területek esetén, továbbá toxikus fémekkel szennyezett talajok esetén a hulladékokkal történő kockázatcsökkentés.

Referencia munkáink között szerepel különböző partnerekkel együttmüködve több szénhidrogénnel szennyezett terület bioremediációja, például ciklodextrinnel intenzifikált bioremediációval $^{11}$, a gyöngyösoroszi ércbánya területére kémiai stabilizálással kombinált fitoremediációs technológia kidolgozása ${ }^{12}$, valamint mikro-szennyezőanyagok eltávolítását célzó ciklodextrin alapú víztisztítási technológiák megalapozása ${ }^{13}$.

\subsubsection{Talajjavítás hulladékokkal}

Csoportunk egyik legújabb kutatási területe a hulladékok felhasználásával történő talajjavítás. A vegyi anyagok használatát, a bányászati tevékenységeket és ezek környezeti kockázatait jól ismerve fordult érdeklődésünk a szennyezett területek felé, majd abból kiindulva a talajromlás irányába. Talajaink védelme, a termőtalajok, mint természeti erőforrások jó minőségének fenntartása, biztosítása; a leromlott szerkezetü talajok szerkezetének és fizikai-kémiai, valamint biológiai tulajdonságainak javítása, melyek révén elérhetővé válik a termőképesség fokozása, mind hazai, mind nemzetközi viszonylatban kiemelt jelentőségü. A jó hulladékgazdálkodás kulcsa pedig a kockázatközpontú koncepció és gondolkodás, a hosszútávú és dinamikus szemlélet. Ezen két problémakörhöz kapcsolódva - a mérnöki tudományok modern eszköztárának felhasználásával újrahasznosítható melléktermékek és hulladékok segítségével - alapoztunk meg és alkalmaztunk innovatív talajjavítási technológiákat leromlott talajokra, például vörösiszap valamint hulladékokból pirolízissel előállított bioszén alkalmazásával 14, 15, 16.

Kutatás-fejlesztési munkánk innovatív koncepciója, hogy ismerjük egyrészt a talaj hiányállapotát jellemző értékeket, másrészt a hulladékokban rendelkezésre álló hasznos anyagokat, értékeket.

A két oldal összehangolásával pedig hatékonyabban mehet végbe mind a leromlott talaj minőségének javítása, mind a szennyezett talajok remediációja.

\subsection{Online Környezetvédelmi Tudásbázis KÖRINFO}

Kutatócsoportunk hozta létre a dinamikusan bővülő lexikont, E-tanfolyamokat, térképes és képtáras adatbázist magában foglaló - KÖRINFO környezetvédelmi tudásbázist és döntéstámogató rendszert ${ }^{17}$, melynek célja, hogy az évek során felhalmozott tudás mindenki számára könnyen elérhetővé váljon, szélesítse a környezetirányításban, a kapcsolódó döntéshozatalban és a mindennapi gyakorlatban szerepet vállaló szakemberek látókörét. A helyes szakmai megoldásokhoz tudás és információ kell, ehhez a tudásbázis modern tudást közvetít, könnyen érthető formában. Felhasználói megismerhetik a modern környezetmérnöki munka tudományos és gyakorlati alapjait, a hagyományos és új környezetvédelmi technológiákat, szemléletes információt kaphatnak a innovatív tudományos és mérnöki eszközökről. 


\section{A Biofinomító csoport kutatásai}

A lignocellulóz hulladékok és melléktermékek rendkívüli jelentőséggel bírnak, mint olcsó, széles körben elérhetö, megújuló szénforrások, melyekből a fosszilis nyersanyagok kiváltására üzemanyagok és értékes kémiai komponensek állíthatóak elő. A biomassza nyersanyagok fenntartható módon történő, teljes körü feldolgozásának igénye hívta életre a biofinomítás fogalmát, mely fogalmat az olajfinomítók analógiájára alkottak meg. Biofinomítás során nyersanyagként biomasszát használunk fel, melyet különböző, integrált feldolgozási lépéseken keresztül számos értéknövelt termékké és energiává alakítunk. Biofinomítás során a biomassza minden komponense felhasználásra kerül. Különös jelentőséggel bír azonban a lignocellulóz nyersanyagok szénhidrát tartalma. A szénhidrátok hidrolízisével nyert monoszacharidokból számos értéknövelt komponens állítható elő mind kémiai szintézis, mind pedig fermentációs eljárások segítségével.

Biofinomító Kutatócsoportunk célja a biomassza melléktermékek biofinomító szemléletben történő, értéknövelt feldolgozásának kutatása. Kutatócsoportunkban főként mezőgazdasági, agro-ipari és egyéb bio-ipari, lignocellulóz tartalmú melléktermékek feldolgozásának lehetőségeit vizsgáljuk. Az utóbbi évek kutatásai során foglalkoztunk kukoricarost, kukoricacsutka, kukoricaszár, búzaszalma, búzakorpa, hulladékpapír, olajbogyó mag, cukorcirok bagasz nyersanyagok biotechnológiai feldolgozásának vizsgálatával, különös tekintettel a következő termékek előállítására: bioetanol, biogáz, xilit, arabinóz, xilooligoszacharidok, itakonsav, celluláz enzimek.

Kutatásaink során laboratóriumi és félüzemi kísérleteket, valamint folyamatmodellezést és technológiai-gazdaságossági számításokat végzünk. Vizsgáljuk a biomassza hidrotermális és kémiai (savas, lúgos) előkezelését, frakcionálását, a szénhidrát frakciók enzimes bontását, valamint a kinyert frakciók fermentációs úton történő továbbalakítását. A kapott kísérleti eredményeket és irodalmi adatokat felhasználva pedig teljes biofinomító folyamatok számítógépes modellezését, különböző konfigurációk technológiai-gazdaságossági összehasonlítását tudjuk elvégezni.

\section{A Szennyvíztisztítási biotechnológiák csoport kutatásai}

A Szennyvíztisztítási Biotechnológiák Kutatócsoport a kommunális és ipari szennyvizek költséghatékony biológiai tisztításának feladathoz igazított kidolgozásával foglalkozik. Fontos alapkoncepciónk az, hogy napjainkban az ún. lakosegyenérték (LE) alapján történő tervezés, ami abból indul ki, hogy a szennyvíztisztító telepre beküldött szennyvíz minősége kiszámolható a lakosok által legalábbis átlagosan megadható kibocsájtott szennyezőanyag mennyiségek és vízmennyiségek lakosok számával való beszorzásával, hazánkban és nemzetközi viszonylatban sem tartható. A különböző csatornarendszerekbe különböző körülmények között és szokásokkal élő lakosok által bebocsájtott szennyvíz mennyisége és minősége is igen jelentősen különbözhet, minden konkrét esetben alapos vizsgálattal meghatározandó. Számos széleskörü felmérésünk azt mutatja, hogy a kiterjedő csatornarendszerekben a szennyvíz egyre hosszabb ideig tartózkodik, ami alatt, különösen a nyári melegben a jól biodegradálódó szerves szénforrás mennyisége csökken, a takarékosság céljából és egyes ipari üzemek bezárásával csökkenő szennyvíz mennyiségben pedig betöményedik az ammónia ${ }^{18}$. Ilyenformán a biológiai nitrogén eltávolítás befejező lépéséhez, a nitrifikáció nyomán keletkező nitrát nitrogén gázt képező denitrifikálásához kevés lesz a felvehető szénforrás, amit nemzetközi viszonylatban egyre gyakrabban pótolnak vegyszeresen, ún. pótszénforrással.

Kutatócsoportunk a csatornarendszerbeli hosszú tartózkodási idő következtében előálló problémák költségkímélő, biotechnológiai megoldásával több szempontból is foglalkozott. Kimutattuk azt, hogy a csatornarendszerek anaerob csőreaktorokként üzemelnek, és így a falon megtelepedett biofilm baktériumai a biodegradációs termékeket egymásnak átadva, az anaerobitás elmélyülésével egyre inkább büzös és korrozív anyagokat állítanak elö ${ }^{19}$. Laboratóriumi modellkísérletek alapján a Dunántúli Regionális Vízmü Zrt-vel közösen olyan, nemzetközi viszonylatban is kiemelkedő hatékonyságú, automatizált biotechnológiai eljárást dolgoztunk ki, mellyel biztonságosan és hatékonyan előzhető meg a büzképződés és a mütárgyakban súlyos károkat okozó korrózió az azokért döntően felelős mikroorganizmusokat elnyomó, denitrifikáló mikroorganizmusok visszafogott elszaporításával.

Hasonló koncepció alapján, kutatásaink oda vezettek el, hogy a biológiai N- és P-eltávolításban valamint a világszerte leginkább elterjedt, ún. eleveniszapos szennyvíztisztításban döntő fontosságú biomassza szerkezet kialakításában használt, nem levegőztetett reaktorokból a lecsökkent szerves szénforrás mellett teljesen ki kell zárni az oxigén bejutását. Az oxigén felhasználása ugyanis minden további reakcióval szemben ún. metabolikus előnyt élvez és emellett jelenlétében kinetikai gátlás is előállhat. A Karsai Müanyagtechnika Holding Zrt-vel együttműködve, a Fővárosi Csatornázási Müvek Zrt. által támogatott közös kutatásban nemzetközi viszonylatban elsőként fejlesztettük ki az un úszó fedlapot a nem-levegőztetett reaktorok mindeddig fedetlen felszínének lezárására ${ }^{20,21}$. Ez a technológiai fejlesztés elnyerte a Pro Progresszió alapítvány 2016 évi Innovációs Díját.

Hazai és széleskörü nemzetközi együttmüködésben több tekintetben is foglalkoztunk az optimalizált bioreaktor elrendezés által nyújtott hatékonyságnövelés lehetőségeivel. Nemzetközi viszonylatban is elsők között alakítottunk ki fonalas baktériumok túlszaporodását gátló, a biomassza ülepedését elősegítő szelektorokat az Északpesti Szennyvíztisztító Telepen kommunális szennyvizek tisztítására, éppen ellenkező irányban pedig fonalas baktériumok növekedésének serkentésére, a tisztított szennyvíz „szürésére” dolgoztunk ki a bioreaktorokbeli szubsztrátgradiens csökkentésén alapuló eljárást biológiailag bontható, mérgező anyagok eliminációjában a baseli Sandoz később Novartis - cég gyógyszer- és vegyszergyártó részlegének szennyvíztisztító telepén ${ }^{22}$. Anaerob szelektorok alkalmazásával serkentettük N- és/vagy P-hiányos szennyvizek tisztítása során a szerves szénforrás többletét a sejtjeikben felhalmozó, ún. glikogénakkumuláló mikroorganizmusok növekedését, ezáltal szükségtelenné téve a pót $\mathrm{N}$ - és/vagy P-adagolást ${ }^{23}$. 
Az optimalizált bioreaktor elrendezésű eleveniszapos szennyvíztisztítást a hatékonyságnövelés érdekében kötöttágyas bioreaktorokkal kombinálva, együttmüködésben a BME Kémiai és Környezeti Folyamatmérnöki Tanszékkel pedig fizikai-kémiai elő, ill. utókezeléssel kiegészítve is alkalmaztuk. Ezek elsősorban biológiailag bontható, mérgező szennyezőanyagok eltávolításában nedves oxidációt, desztillációs eljárásokat és membránszürést jelentettek ${ }^{24}$. A különböző határterületek együttmüködését az elörelépés fontos lehetőségének tartjuk, ennek szellemében a BME Viziközmü és Környezetmérnöki Tanszékével folytatunk egymást kiegészitő kutatást. Kutatási módszereink laboratóriumi szakaszos és folytonos üzemü modellkísérleteket, matematikai szimulációs számításokat és üzemi rendszerek mintázását, az egyes egységekben lejátszódó folyamatok ún. profilmérésekkel való követését egyaránt magukban foglalják.

\section{Hivatkozások}

1. Anastas, P. T.; Warner, J. C. Green Chemistry: Theory and Practice, Oxford University Press: New York, 1998, p.30.

2. Hetényi Kata, Németh Áron, Sevella Béla: Fehér Biotechnológiai Kutatások, MAGYAR KÉMIAI FOLYÓIRAT - KÉMIAI KÖZLEMÉNYEK (1997-), 2008, 114, 102-106.

3. Hetényi K.: Biofinomító technológiáinak optimalizálása, $\mathrm{PhD}$ értkezés (BME), 2010

4. Németh Á., Kaleta Z. Complex utilization of dairy waste (whey) in Biorefinery, WSEAS TRANSACTIONS ON ENVIRONMENT AND DEVELOPMENT, 2015, 11, 80-88.

5. Vidra A., Németh Á., Whey utilization in a two-stage fermentation process, LIQUID WASTE RECOVERY,

2017,2 (1) https://doi.org/10.1515/lwr-2017-0004

6. Vidra A., Tóth A. J., Németh Á. Lactic acid production from cane molasses LIQUID WASTE RECOVERY, 2017, 2(2) pp. 5-11.

7. Németh Á., Eritrit fermentációs előállítása, 362. KÉKI Tudományos Kollokvium, Budapest, Magyarország, 2016.02.19

8. Tapasztó A., Németh Á., Sevella B. Examination of entomopathogenic fungi on western corn rootworms Acta Microbiologica et Immunologica Hungarica: Abstracts of the Annual Meeting of the Hungarian Society for

Microbiology, Keszthely, Magyarország, 2012, p. 31.

9. Gruiz, K., Fekete-Kertész, I., Kunglné Nagy, Zs., Hajdu, Cs., Feigl, V., Vaszita, E., Molnár, M. Direct toxicity assessment - methods, evaluation, interpretation, Science of The Total Environment, 2016, 563-564, 803-812

10. Fekete-Kertesz, I., Piszman, D., Molnár, M. Particle size and concentration dependent ecotoxicity of nano- and microscale $\mathrm{TiO} 2$-comparative study by different aquatic test organisms of different trophic levels, Water Air \& Soil Pollution, 2017, 228-245 https://doi.org/10.1007/s11270-017-3394-5

11. Molnár, M., Leitgib, L., Gruiz, K., Fenyvesi, É., Szaniszló, N., Szejtli, J., Fava, F. Enhanced biodegradation of transformer oil in soils with cyclodextrin - from the laboratory to the field - Biodegradation, 2005, 16, 159-168. https://link.springer.com/article/10.1007\%2Fs10532-004-4873-0

12. Feigl, V., Gruiz, K., Anton, A. Remediation of metal ore mine waste using combined chemical- and phytostabilisation, Periodica Polytechnica, 2010,54 (2), 71-80. https://doi.org/10.3311/pp.ch.2010-2.03
Az utóbbi években kutatócsoportunkban új kutatási téma az ún. mikrobiológiai üzemanyagcellák fejlesztése. A mikrobiológiai üzemanyagcellák alkalmazása merőben új lehetőséget teremt megújuló elektromos energia előállítására. Baktériumok egy speciális csoportja, az ún. exoelektrogének a szerves anyagok (pl. acetát, etanol, szennyvizek szennyező anyag tartalma) oxidálásából nyert elektronokat - szigorúan anaerob környezetben - képesek közvetlenül a cella anódjára transzportálni, így közvetlenül a szerves anyag lebontásából nyerhető elektromos energia. Ezt kihasználva a mikrobiológiai üzemanyagcellákat szennyezés eliminációs rendszerekben alkalmazva energia hatékony, ill. energiavisszanyerésre alkalmas technológiák alakíthatók ki. Kutatócsoportunk a mikrobiológiai üzemanyagcellákban zajló folyamatok kinetikai vizsgálatával és hatékonyságának továbbfejlesztésével foglalkozik ${ }^{25}$.

13. Nagy, Z.M., Molnár, M., Fekete-Kertész, I., Molnár-Perl, I., Fenyvesi, E., Gruiz, K. Removal of emerging micropollutants from water using cyclodextrin, Science of the Total Environment, 2014, 485-486, 711-719. https://doi.org/10.1016/j.scitotenv.2014.04.003

14. Ujaczki, É., Feigl, V., Farkas, É., Vaszita, E., Gruiz, K., Molnár, M. (2016) Red mud as acidic sandy soil ameliorant: a microcosm incubation study, Journal of Chemical Technology \& Biotechnology, 2016, 91 (6), 1596-1606. doi: 10.1002/jctb.4898 https://doi.org/10.1002/jctb.4898

15. Ujaczki, É., Feigl V., Molnár, M., Vaszita E., Uzinger, N., Erdélyi A., Gruiz, K. The potential application of red mud and soil mixture as additive to the surface layer of a landfill cover system: field-study, Journal of Environmental Sciences, 2016, 44, 189-196. https://doi.org/10.1016/j.jes.2015.12.014

16. Molnár, M., Vaszita, E., Farkas, É., Ujaczki, É., Fekete-Kertész, I., Tolner, M., Klebercz, O., Kirchkeszner, Cs., Gruiz, K., Uzinger, N., Feigl, V. Acidic sandy soil improvement with biochar - a microcosm study, Science of the Total Environment, 2016, 563-564, 855-865. https://doi.org/10.1016/j.scitotenv.2016.01.091

17. KÖRINFO Online Tudásbázis és Döntéstámogató Rendszer - Dinamikus információs rendszer a környezethatékony és környezettudatos döntéshozatal szolgálatában. www.körinfo.hu / www.enfo.hu

18. Tardy, G.M., Bakos V. and Jobbágy, A. Conditions and technologies of biological wastewater treatment in Hungary. Water Science and Technology, 2012, 65(9), 1676-1683, https://doi.org/10.2166/wst.2012.062

19. Jobbágy, A., Szántó, I., Varga, Gy. I., Simon, J. Sewer system odour control in the Lake Balaton area, Water Science and Technology, 1994, 30(1), 195-204. https://doi.org/10.2166/wst.1994.0021

20. Wanner, J. and Jobbágy, A. Activated sludge solids separations. Jenkins, D. and Wanner, J. [Eds.] in Activated sludge - 100 years and counting, 2014, IWA Publishing, Glasgow, UK:171-193.

21. Jobbágy, A., Weinpel, T., Bakos, V., Vánkos, Zs. Factors potentially converting non-aerated selectors into „low-S low-DO basins", effects of seal-covering. $12^{\text {th }}$ IWA Specialised Conference on LWWTPs, 6-9 Sept., 2015, Prague, Czech Republic. Proc. 149-155.

22. Jobbágy, A., Németh, N., Altermatt, R.H., Samhaber, W.M. Encouraging filament growth at an activated sludge treatment plant of the chemical industry, Water Research, 2000, 34(2), 699-703. https://doi.org/10.1016/S0043-1354(99)00149-9

124. évfolyam, 3. szám, 2018. 
23. Kiss, B., Bakos, V., Liu, W-T, Jobbágy, A. Full-Scale Use of Glycogen-Accumulating Organisms for Excess Biological Carbon Removal, Water Environment Research, 2011,83(9), 855-864, https://doi.org/10.2175/106143010X12851009156844

24. Szabados, E., Jobbágy, A., Tóth, A.J., Mizsey, P., Tardy, G., Pulgarin, C., Giannakis, S., Takács, E., Wojnárovits, L., Makó, M. and Trócsányi, Z. Complex Treatment for the Disposal and Utilization of Process Wastewaters of the Pharmaceutical Industry, Periodica Polytechnica Chemical Engineering, 2017, online available:

https://pp.bme.hu/ch/article/view/10543

https://doi.org/10.3311/PPch.10543

\section{Researches on environment technologies}

In this report we summarized the broad range of researches on environmental technologies carried out by four individual research groups of the Department of Applied Biotechnology and Food Science.

First Fermentation Pilot Plant Research Group was introduced along the 12 principles of Green Chemistry: 1) Under prevention of waste forming we shortly mentioned our researches on whey (dairy waste) conversion into propionic acid in two stage fermentation (LAB+PAB); 2) For Atom Economy we introduced our recent results on lactic acid fermentation, since it provides high yields over 95\% from several substrates including appropriate pretreated molasses; 3) Under Less Hazardous Chemical Syntheses we showed, how eritrytol can be produced via osmophilic yeast fermentation in place of catalytic hydrogenation; 4) For Designing Safer Chemicals we reported manufacturing a bioinsecticide on entomopathogen fungi basis against corn root worm; 5) Under Safer Solvents and Auxiliaries we showed a solution for removing molybdenate from mining drain water with the help of a biosorbent, which can be used for soil enhancement as well; 6) For Energy Efficiency we introduced our researches on fermentative bacterial cellulose production, which is more simple and energy efficient versus physico-chemical pre-treatments of plant biomass. 7) Under Use of Renewable Feedstocks we shortly mentioned an industrial research on fly grub utilization in a biorefinery via fractionation of the raw material; 8) For Reduce Derivatives, we presented a recently started research on 25-hydroxylation of ergosterol with the help of a bacterial cytochrome for production of vitamin D2. 9) For Catalytic and very selective reagents we showed the enzymatic bioconversion of glycerol into 1,3-propanediol, because we have already verified, that 3 appropriate enzyme of the anaerobic glycerol metabolism are able to produce 1,3-propanediol, but the best enzyme source is still under searching. 10) Under the term Design for degradation despite mentioning the PLA (poly-lactic acid) of which monomer can be fermented resulting biodegradablilty, we focused on the bacterial production of biodetergents, which are certainly also biodegradable, and for which we successfully adapted a surface tension measurement method. With the application of this measurement, we compared the effect of different fermentation-temperatures on biodetergent activity. 11) For Real-time analysis for Pollution Prevention we introduced our diatom fermentation, since these microorganism are very sensitive against environmental change, therefore they can indicate the occurance of pollutions.Finally 12), under this
25. Tardy, G.M., Lóránt, B. and Lóka, M. Substrate concentration dependence of voltage and power production characteristics in two-chambered mediator-less microbial fuel cells with acetate and peptone substrates, Biotechnology Letters, 2017, 39(3), 383-389 https://doi.org/10.1007/s10529-016-2256-3

topic, we presented our new method for detecting and quantifying product contaminating microorganism through an impedimetric measurement called BacTrac.

The next research group introducing here is the Research group for Environmental Microbiology and Biotechnology focusing on two major fields of environment protection: risk assessment and risk reduction. For risk assessment, this research group elaborate different tests since 25 years, including such environment monitoring methods like application of Alivibrio fisherii, Lemna minor, Tetrahymena pyriformisor Daphnia magna etc. A recent direction is to adapt, develop and improve tests for microcontaminant materials occurring and having effects even in very low concentrations. Researches for risk reductions have several directions: 1) soil and groundwater remediation with the help of cyclodextrins or phytoremediation 2) soil improvements with application of wastes (like bio-carbon) 3) development of the ENFO environmental and engineering database.

The Biorefinery Research Group focuses on the complex utilization of agricultural and agro-industrial by-products according to the concept of biorefinery. Over the past decades the research group has investigated different lignocellulosic materials, e. g. sweet sorghum bagasse, corn fibre, corn stover, wheat straw, wheat bran, waste paper, and olive stone to produce bioethanol, biogas, xylitol, arabinose, xylo-oligosaccharides, itaconic acid, cellulase enzymes. Generally, the experiments are carried out on a laboratory scale, and the obtained results are also used in process simulations to assess the techno-economic performance of the investigated process.

Finally, the Biotechnologies in Wastewater Treatment research group presented main research activities connectable to increasing retention times in sewer systems and resulting odour and corrosion problems as well as decreasing carbon source availability and their solutions, including the pioneer technology of excluding oxygen penetration from non-aerated activated sludge reactors. Research for optimization of bioreactor arrangement as well as application of combined activated sludge- biofilm systems aim to have high-rate removal of nutrients as $\mathrm{N}$ and $\mathrm{P}$ and obtain optimal activated sludge floc structure. Combining pre- and post- physico-chemical treatment has also been applied for removing toxic organics. Investigation of microbial fuel cells for kinetic studies and increasing efficiency has also been fit into the wide-range topics. 